Preprints of the

Max Planck Institute for

Research on Collective Goods

Bonn 2013/10

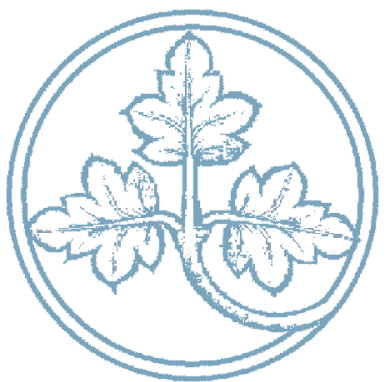

Does Political Representation through Parties Decrease Voters' Acceptance of Decisions?

Emanuel Towfigh

Andreas Glöckner Sebastian J. Goerg

Philip Leifeld

Carlos Kurschilgen

Aniol Llorente-Saguer

Sophie Bade

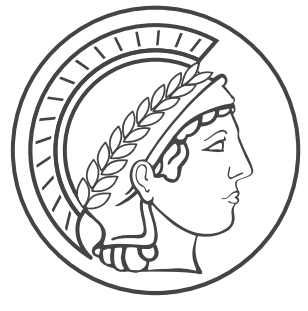




\title{
Does Political Representation through Parties Decrease Voters' Acceptance of Decisions?
}

\author{
Emanuel Towfigh / Andreas Glöckner / Sebastian J. Goerg / Philip Leifeld
}

Carlos Kurschilgen / Aniol Llorente-Saguer / Sophie Bade

May 2013 


\title{
Does Political Representation through Parties
}

\section{Decrease Voters' Acceptance of Decisions?*}

\author{
Emanuel Towfigh $^{\mathrm{a}}$ Andreas Glöckner ${ }^{\mathrm{a}, \mathrm{b}}$ Sebastian J. Goerg ${ }^{\mathrm{c}}$ \\ Philip Leifeld $^{\dagger \mathrm{d}, \mathrm{C}} \quad$ Carlos Kurschilgen $^{\mathrm{a}} \quad$ Aniol Llorente-Saguer ${ }^{\mathrm{a}}$ \\ Sophie Bade ${ }^{\mathrm{f}}$
}

${ }^{a}$ Max Planck Institute for Research on Collective Goods

b University of Göttingen, Georg Elias Müller Institute of Psychology

${ }^{c}$ Florida State University, College of Social Sciences and Public Policy

${ }^{\mathrm{d}}$ University of Konstanz, Department of Politics \& Public Administration

e Swiss Federal Institute of Aquatic Science and Technology (Eawag)

${ }^{f}$ Royal Holloway University of London, Department of Economics

May 28, 2013

${ }^{*}$ We are grateful to Steve Ansolabehere, Paul Bauer, Becky Morton, Isabelle Stadelmann-Steffen, as well as the participants of seminars at NYU and the Workshop on Political Parties (Bonn) for very helpful comments.

${ }^{\dagger}$ Corresponding author. University of Konstanz, Box 216, 78457 Konstanz, Germany. E-mail: philip.leifeld@uni-konstanz.de. 


\begin{abstract}
Are decisions by political parties more or less accepted than direct-democratic decisions? The literature on parties as brand names or labels suggests that the existence of political parties lowers information and transaction costs of voters by providing ideological packages. Building on this important argument, we posit that this informational rationale for parties is not universally applicable and is contingent on the context of the decision that is made. Intermediary political decision-making institutions may impose additional costs on voters in situations where the decision is perceived to be personally important to the individual voter. We conduct an experimental online vignette study to substantiate these claims. The results imply that a combination of representative democracy and direct democracy, conditional on the distribution of issue importance among the electorate, is optimal with regard to acceptance of a decision.
\end{abstract}


Are decisions by political parties more or less accepted than direct-democratic decisions? We conduct an experimental online survey to disentangle voters' procedural acceptance of both decision-making mechanisms and finally compare it to the acceptance of expert committees as a third mode of political decision-making. With our results, we seek to qualify the literature on parties as brand names or labels (e.g., Aldrich 1995; Arceneaux 2008; Ashworth and Bueno de Mesquita 2008; Butler and Powell 2012; Cox and McCubbins 1993; Druckman 2001a; Snyder and Ting 2002).

More specifically, we argue that the acceptance of decisions does not vary per se and irrespectively of context between different modes of decision-making. Instead, it is is contingent on the subjective importance that a voter attributes to the issue under consideration, controlling for personal agreement with the outcome of the decision that is made. Previous research indicates that personally important issues increase people's motivation to systematically process arguments. In contrast if they consider an issue of little importance, they tend to rely on partisan cues (Petty and Cacioppo 1986). We argue that if voters' core interests are at stake, they prefer more individual, immediate control over important decisions instead of a decoupling of decisions from the electorate through intermediary decision-makers. Political decisions on topics in which voters are slightly less interested, however, are equally well accepted no matter how the decision comes about, and unimportant political decisions may be best delegated to representatives. We argue that political parties rightly assume their role of lowering transaction costs of voters for everyday decisionmaking, but they do less well in terms of acceptance for important political decisions.

Our argument is structured in the following way. The first section compares theoretical arguments in favor of and against the acceptance of decision-making by political parties and direct democracy, respectively. We set out four hypotheses regarding the procedural acceptance of the different decision-making modes. This is followed by a description of the methodology of survey experiments, the setup of our study, the data collection, and our dataset. After the discussion of the results, 
we discuss the broader implications of our findings and suggest avenues for future research.

\section{Political parties versus direct democracy}

How can the people's will best be mapped into political outcomes? This is a longstanding question in the history of democratic thought. In representative democracies, political parties have emerged, which channel their members' preferences (Katz 1990; Schlesinger 1984) and maximize their vote share (Becker 1958; Downs 1957) or their benefits from holding office (Schlesinger 1975). In a historical perspective, parties were originally a means of elites to maintain control over the masses (Bernard 1997). Parties are able to overcome the collective action problems which would be associated with a system where many unorganized, individual leaders would seek office (Aldrich 1995).

The addressees of parties, the general population, in turn tolerate parties as long as they are "functional". The literature on parties as brand names (Aldrich 1995; Arceneaux 2008; Ashworth and Bueno de Mesquita 2008; Butler and Powell 2012; Cox and McCubbins 1993; Druckman 2001a; Snyder and Ting 2002) suggests that the electorate deems parties functional because they provide informational packages as platform signals to the uninformed voters. Party labels serve as cognitive heuristics that help the electorate make meaningful non-random decisions and choose policy positions on novel issues (Arceneaux 2008; Druckman 2001b; Zaller 1992). Private individuals do not have the resources to be well-informed regarding the full range of political problems, hence they delegate this task to political parties and their candidates. Parties thus fulfill an intermediary function by reducing voters' costs of information and aggregating political packages for them (Ashworth and Bueno de Mesquita 2008; Jones and Hudson 1998; Müller 2000; Nisbett and Ross 1992). In this perspective, representation by political parties is functional and accepted be- 
cause they offer a division of labor. Voters are unable to spend large amounts of resources on aggregating information; spending fewer resources on deciding which party offers the best overall position seems more efficient.

However, this system of intermediaries has also been recognized as having several biases in the representation of the people's will, among them the opportunistic political business cycle (Nordhaus 1975), corruption (Heidenheimer and Johnston 2002), other rent-seeking behavior (McCormick and Tollison 1979), and a lack of choice due to platform convergence (Bernhardt, Duggan and Squintani 2009). These weaknesses may affect citizens' satisfaction with the political system and lead to decreased political participation (Scarrow 1999) or even disenchantment with political parties (Klein 2005; Clarke and Stewart 1998).

Moreover, "tensions have grown in most Western nations between the existing processes of representative democracy and calls by reformists for a more participatory style of democratic government" (Dalton, Burklin and Drummond 2001). Recent years have therefore witnessed a tremendous "spread of direct democracy" in many democratic polities (Scarrow 2001; Donovan and Karp 2006). A case in point is the recent effort of the European Union, one of the largest democratic political systems in the world, to curtail its alleged democratic deficit (Karp, Banducci and Bowler 2003) by introducing large-scale referenda (Auer 2005).

On the one hand, research investigated the effect of direct democracy on participation in elections, closely looking at factors on the individual level such as demographic and attitudinal traits, levels of education, or differences in social status (Lacey 2005; Leighley and Nagler 1992; Rosenstone and Hansen 2003; Tolbert and Smith 2005). On the other hand, similar to our study, scholars have documented attitudinal and behavioral effects of direct democratic procedures on citizens (Barber 1984; Mendelsohn and Cutler 2000; Pateman 1970). The literature is divided over the merits of direct-democratic procedures over conventional forms of representative democracy. Proponents of direct democracy argue that direct-democratic 
procedures stimulate voters' political interest by forcing them to think about the contents of a political decision. Direct-democratic procedures educate voters as political citizens (Benz and Stutzer 2004; Smith 2002). Hence they lead to more active participation (Schuck and de Vreese 2011; Tolbert and Smith 2005) and a better representation of the people's will. In other words, the quality of political decisions is increased because voters are better informed.

Others emphasize that frequent ballots lead to voter fatigue and thus decrease rather than increase electoral participation and decision quality (Bowler, Donovan and Happ 1992; Freitag and Stadelmann-Steffen 2010). Biases in the mapping of the people's will to political outcomes may occur because well-endowed organized interests can initiate referenda by buying the initially required number of signatures (for a discussion, see Lupia and Matsusaka 2004; Hasen 2000). Finally, ballot decisions may, under certain circumstances, suppress minorities in favor of the majority (Hajnal, Gerber and Louch 2002; Vatter and Danaci 2010). In other words, the quality of political decisions is decreased because direct-democratic procedures are prone to distortion by specific subgroups of the electorate. These effects, may in turn, reduce acceptance of the outcomes and voter turnout.

While it is not possible to quantify the difference in informational costs between direct democracy and party government, we can compare the mechanisms in terms of acceptance by voters. The notion of acceptance is intimately related to the notion of legitimacy. A distinction can be made between output legitimacy, which is related to the benefits and drawbacks of democratic procedures in terms of outcomes, and input legitimacy, which is provided by the right to vote - even if the vote is for a representative - and which is thus intrinsically related to the people's will (Easton 1965; Scharpf 1999). Input legitimacy - and thus voters' procedural utility (Frey and Stutzer 2005; Stutzer and Frey 2000; Tyler 2006) — is high if voters are comfortable with the way the decision is made, irrespective of the actual outcome. In this perspective, a democratic procedure or institution can be described as legitimate if 
it is associated with a high acceptance by the people (Gibson and Caldeira 1995). Therefore, in this article, we disentangle the functional and dysfunctional aspects of direct-democratic decisions versus decisions made by political parties and use measured acceptance of political decisions as proxies for their (input) legitimacy.

As shown in the discussion above, both direct democracy and representation through political parties seem to have functional as well as dysfunctional elements. We thus posit that the two modes of decision-making do not per se generate different levels of acceptance. This hypothesis is consistent with the usual assumption of outcome-based utilities typically used in rational choice (Becker 1978).

Hypothesis 1 (Parties vs. direct democracy) Controlling for personal opinion on the desired outcome of a decision, there is no difference per se between the acceptance of outcomes of direct democracy and party representation.

The conditions under which acceptance of a decision and its underlying procedure is high or low seem to be complex. Esaiasson, Gilljam and Persson (2012) suggest that acceptance is increased when participation in the decision-making process is implemented. Based on their randomized field experiment, they conclude that "personal involvement is the main factor generating legitimacy beliefs" about distributive decisions. The finding is supported by earlier field experiments of Olken (2010), who concludes that "direct participation in political decision making can substantially increase satisfaction and legitimacy." Similarly, Gash and Murakami (2009) find that control over the decision increases acceptance of the decision: "individuals are more likely to agree with, and less willing to work against, policies that have been produced by their fellow citizens", moderated by partisan affiliation. We seek to qualify these results in a real-world election context at the level of a German federal state. More specifically, we argue that direct democracy is more accepted in situations where the issue to be decided is important for the electorate, whereas the choice of the democratic procedure does not affect citizens' acceptance of the decision when their stakes are in fact low. Political parties thus serve their function as 
brand names (Ashworth and Bueno de Mesquita 2008) and as minimizers of voters' information and transaction costs perfectly well in contexts of everyday decisionmaking. Direct-democratic procedures, in contrast, are more accepted means of democratic decision-making in situations where voters are intrinsically interested in obtaining more information. Two potential channels are well exemplified with rational voter models: higher stakes would increase both turnout (e.g., Palfrey and Rosenthal 1985) and collective information gathering (Martinelli 2006). For these relevant issues, citizens prefer the electorate to exercise more control, whereas the decoupling of the political sphere from the auspice of the voters is an acceptable tradeoff for less important issues.

Hypothesis 2 (Importance of the decision) The more important an issue is for the individual voter, the less the voter accepts the decision if it is made by political parties, and the more the voter accepts it if it is made by means of direct democracy.

The policy implication of this argument is that a mix of representative democracy in "normal policy-making" contexts enhanced by direct-democratic decisions during "hot debates" is more promising than current decision-making practices in the majority of industrialized democracies - if acceptance of decisions is adopted as the ultimate benchmark for democratic aggregation of the political will. This, in turn, can presumably explain recent civil unrest in Western democracies after highly relevant incidents, which were largely decoupled from the individual citizen's sphere, such as nuclear energy policy after the Fukushima meltdown, the Occupy movements, or the "Stuttgart 21" protests in Germany (for details on the cases and the alleged "new protest culture", see Hartleb 2011).

In spite of this observation, it does not imply that acceptance of a decisionmaking mode is merely scenario-driven, but dependent on inter-individual differences in the perception of importance. Citizens reject representation by intermediaries in situations which are personally important to them; but this is not only determined 
by the overall importance of, say, the Fukushima accident or similarly prevalent issues in the media. We predict that the importance effect rather prevails across voters even within issue categories like nuclear energy policy decisions.

Hypothesis 3 (Importance effect is not scenario-driven) The interaction between importance of a decision and decision-making procedure on acceptance persists independently of the issue.

Finally, our previous arguments imply that other decision-making procedures which rest on representation through intermediaries are similarly outperformed by a direct-democratic procedure on relevant issues with a high perceived importance. More specifically, decisions made by expert committees should suffer from similar legitimacy deficiencies as decisions made by political parties, or conversely, direct democracy should lead to significantly higher acceptance rates than expert panels because the latter are decoupled from the individual control sphere of the electorate in a similar way to political parties.

Hypothesis 4 (Expert committees) With increasing issue importance, a directdemocratic procedure generates stronger acceptance rates than political decisions by expert committees.

We substantiate these claims by presenting evidence from an online survey experiment conducted before the March 2011 state-level election in Rhineland-Palatinate, one of the 16 German federal states (Länder). As described in the next section, we employed a $3 \times 5 \times 2$ factorial design to test for differential acceptance rates of political decisions, varying the decision-making mechanism, the issue scenario, and a positive versus negative framing of the decision problem.

\section{Data collection and methodology}

Our dataset was collected between the tenth and the fifth day before the 2011 state election in Rhineland-Palatinate, which has a population of about four million inhab- 
itants. 711 persons eligible to vote were contacted and incentivized by a professional online panel provider. 86.5 percent (615 persons) completed the questionnaire, which took about twelve minutes on average. Two persons were excluded due to unreasonable age specifications of two and four years, respectively. All analyses presented below are executed on the remaining $n=613$ participants. Respondents were between 18 and 70 years old (mean $=44.3$ years), and the share of female participants was 50.7 percent. In terms of age and gender, our sample is roughly representative of the voting population of the state of Rhineland-Palatinate.

Our research design is an experimental vignette study, which should allow us to study the potential influence of different decision-making institutions on the acceptance of political decisions. Each respondent faced three different political issues in random order as a within-subjects factor: nuclear energy (scenario 1), school graduation (scenario 2), and religious education (scenario 3). For each participant, one out of five decision tasks was randomly selected, varying the institution that makes the decision (two specific parties (CDU and SPD), the majority of parties, an expert committee, or by a direct-democratic procedure ${ }^{1}$ ). Moreover, the framing of the decision as a positive or negative outcome was randomly allocated in order to cancel out potential biases due to question wording interacting with personal opinion. Hence, the vignette study has a structure of a 3 (issue scenario) $\times 5$ (decision-making procedure) $\times 2$ (positive/negative outcome) array.

For the first factor, the issue scenario, we used three different political topics taken from an online voting tool called "Wahl-O-Mat" (http://www.wahl-o-mat. de/rlp2011/, last accessed February 26, 2013). This tool is run by a federal agency subordinated to the Federal Ministry of the Interior. It was set up to help voters compare their own political preferences with the official issue stances of the competing political parties and find their best match for the upcoming election. As such,

\footnotetext{
${ }^{1}$ In an earlier version of this paper, we used "plebiscite" - the phonetic German equivalent of which is a synonym for direct-democratic procedures generally - as a translation for what we now translate as "direct-democratic procedure". We have come to understand that the former translation may lead to confusion in the US context.
} 
it is a screening device for voters to learn about the ideal points of parties before an election. We adopted issue scenarios from this tool to ensure the real-world relevance of our questions.

The first scenario is about nuclear power. In the online survey, the following task was set:

"Please imagine that after the state election on March 27, 2011, the majority of the Members of Parliament of Rhineland-Palatinate (of various parties) makes the following decision concerning nuclear power: The state of Rhineland-Palatinate will [will not] campaign for revising the decision concerning longer remaining service lives for nuclear power plants." Translated from the original German online questionnaire; emphasis added, negative frame given in square brackets.

The second issue scenario is about the introduction of a centralized secondary school-leaving examination (instead of a decentralized examination). In this case, the second emphasized text portion in the above decision task was replaced by: "The centralized high-school examination will [will not] be introduced in RhinelandPalatinate." Topic 3 deals with the introduction of Islamic education in public schools: "Public schools in Rhineland-Palatinate should [should not] offer Islamic religious education in German language."

Issue scenario 1 generated the most public interest during the data collection phase because the Fukushima meltdown had occurred shortly beforehand. We control for this potential bias of issue scenarios in the context of hypothesis 3 .

The differential effects of five decision-making procedures are tested by the following replacements of the first emphasized text portion in the above task: a) "based on a direct-democratic procedure, the following decision is made"; b) "a commission of experts is installed, which comes to the following decision"; c) "the majority of the members of Parliament of Rhineland-Palatinate follow a petition of the ChristianDemocratic Party and make the following decision concerning nuclear power"; d) 
"the majority of the members of Parliament of Rhineland-Palatinate follow a petition of the Social-Democratic Party and make the following decision concerning nuclear power"; and e) "the majority of the members of Parliament (from diverse parties) makes the following decision concerning nuclear power." These descriptions correspond with a decision made by a) a direct-democratic procedure; b) an expert committee; c) the party CDU; d) the party SPD; e) the majority of parties, i.e., the parliament.

The scenarios were presented in random order one at a time, keeping the decisionmaking procedure fixed. For each scenario, we measured agreement with the contents of the decision, acceptance of the decision, and importance of the topic. Agreement was assessed by letting respondents indicate whether the decision was in line with their personal opinion on a scale from 1 (not at all) to 4 (completely) with unlabeled intervals between the endpoints.

Our dependent variable, acceptance of the decision, was measured using a selfconstructed six-item battery on a scale from 1 (very little or not at all) to 5 (extremely), again with unlabeled intervals between the endpoints. Persons indicated agreement to the following items: 1) I accept the decision; 2) the decision makes me angry; 3) the decision deserves my active support; 4) the decision activates my opposition; 5) I am shocked by the decision; 6) the decision makes me feel helpless (items 2, 4, 5 and 6 with reversed scales). The aggregate acceptance scale was generated for each scenario separately with high scale reliabilities in each scenario (Cronbach's alpha for the different scenarios: nuclear $\alpha=0.909$; school $\alpha=0.834$; religion $\alpha=0.879)$.

Participants rated the importance of the topic on the same scale from 1 to 5 . The decision-making procedure was held constant over scenarios per participant to avoid effects due to the salience of different procedures.

We further measured affective response, which was highly correlated with acceptance and brought no further insights. Participants rated their affective response 
to the decision by indicating on the same scale how angry, happy, nervous, and excited they felt about the decision. For simplicity, we will not report data from this measure.

\section{Results}

Tables 3 and 4 present the results of twelve random effects generalized least squares (GLS) models. Models 1-5 are based on a reduced dataset where political parties and direct democracy are compared with regard to acceptance of decisions. Models 6-12 are based on the full dataset, which contains decisions made by expert committees as a third decision procedure. Variables are centered in all models, both for the main effects and the interaction effects. ${ }^{2}$ Tables 1 and 2 show the summary statistics for the variables contained in the regression models for a reduced and for the full dataset, respectively.

\section{Acceptance of outcomes from parties versus direct democracy}

The dependent variable in all models is the acceptance of the decision by the respondent. Personal agreement with the outcome of the decision is the most important control variable. We are primarily interested in the variation in acceptance conditional on decision modes and holding personal opinion on the issue constant. In this regard, model 1 tests whether decisions by political parties are significantly less accepted than decisions made with direct-democracy (the reference group). The Party variable is a composite dummy which is positive if either SPD, CDU or Parl is positive. It thus captures the pooled effect of decisions made by political parties vis-a-vis direct democracy. Quite obviously, parties do not seem to be dysfunctional

\footnotetext{
${ }^{2}$ We use centered variables for the interaction effects, as they allow to interpret the coefficients of the main variables as the main effects. Replacing the centered main variables with the uncentered ones would not change the estimates as long as the interaction effects stay centered.
} 


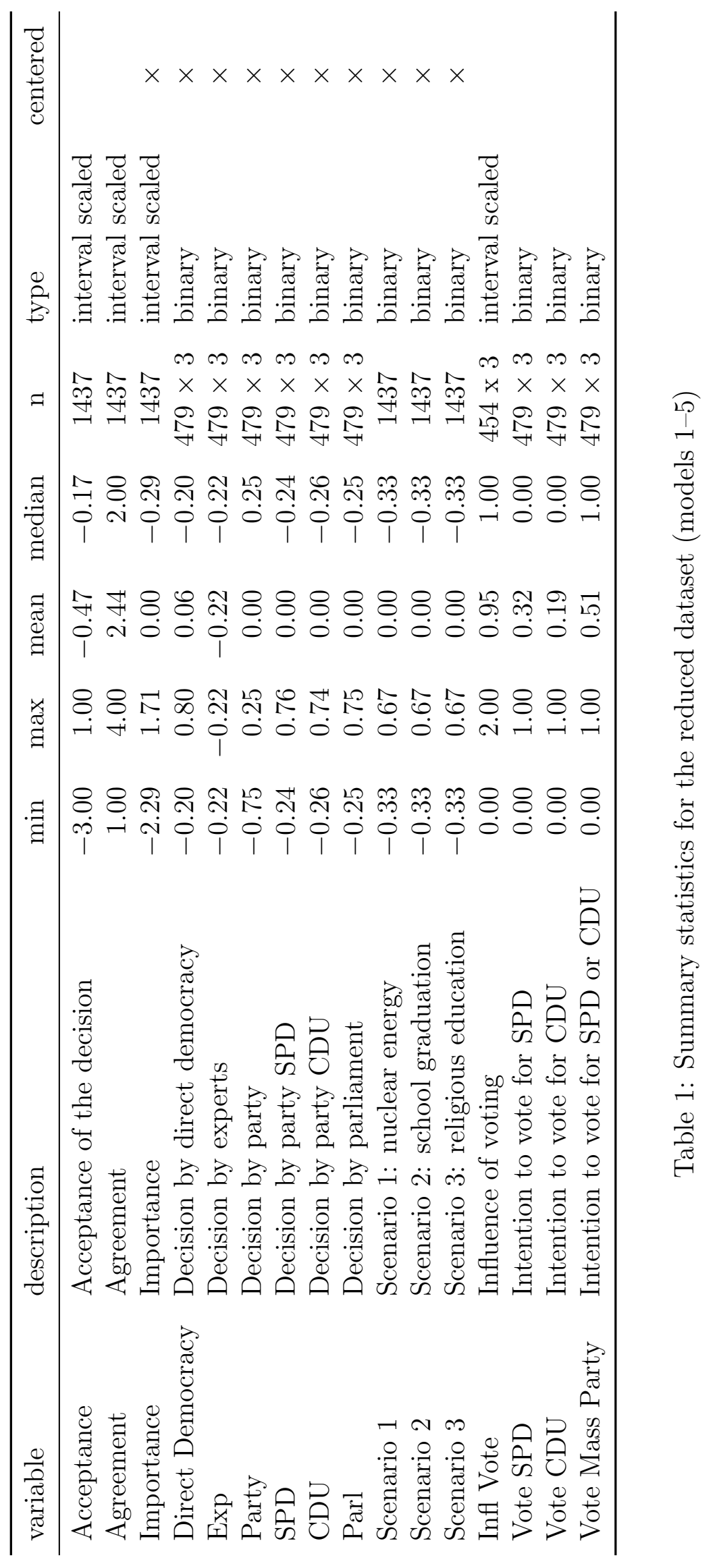




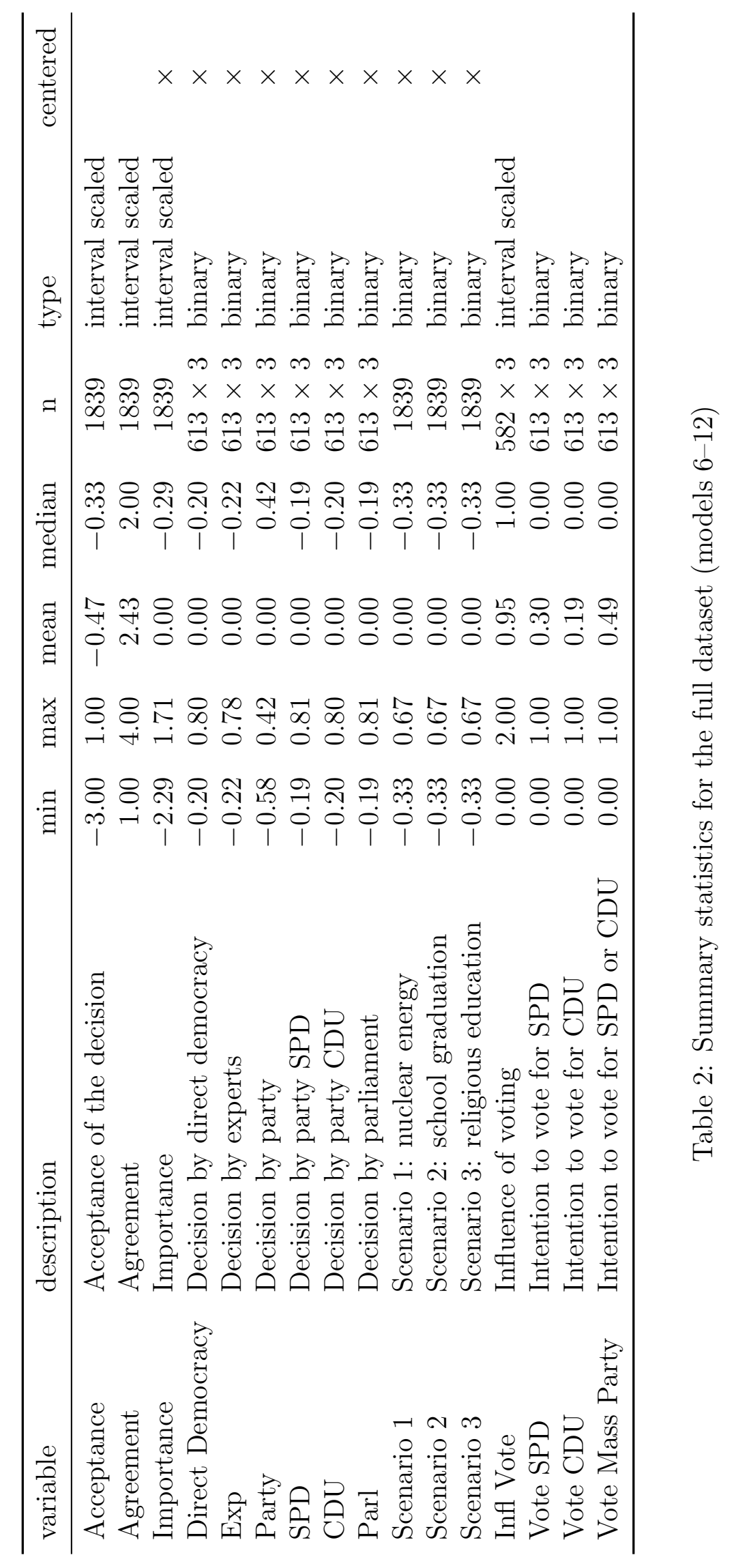




\begin{tabular}{|c|c|c|c|c|c|}
\hline & Model 1 & Model 2 & Model 3 & Model 4 & Model 5 \\
\hline (Intercept) & $\begin{array}{c}-2.26^{* * *} \\
(0.06)\end{array}$ & $\begin{array}{c}-2.30^{* * *} \\
(0.04)\end{array}$ & $\begin{array}{c}-2.30^{* * *} \\
(0.04)\end{array}$ & $\begin{array}{c}-2.30^{* * *} \\
(0.04)\end{array}$ & $\begin{array}{c}-2.44^{* * *} \\
(0.06)\end{array}$ \\
\hline Party & $\begin{array}{c}-0.04 \\
(0.05)\end{array}$ & $\begin{array}{c}-0.04 \\
(0.05)\end{array}$ & $\begin{array}{c}-0.04 \\
(0.05)\end{array}$ & $\begin{array}{c}-0.04 \\
(0.05)\end{array}$ & $\begin{array}{c}-0.05 \\
(0.05)\end{array}$ \\
\hline Agreement & $\begin{array}{l}0.75^{* * *} \\
(0.02)\end{array}$ & $\begin{array}{l}0.75^{\text {*** }} \\
(0.02)\end{array}$ & $\begin{array}{l}0.75^{* * *} \\
(0.02)\end{array}$ & $\begin{array}{l}0.75^{* * *} \\
(0.02)\end{array}$ & $\begin{array}{l}0.76^{\text {*** }} \\
(0.02)\end{array}$ \\
\hline Importance & & $\begin{array}{c}-0.19^{* * *} \\
(0.01)\end{array}$ & $\begin{array}{c}-0.18^{* * *} \\
(0.02)\end{array}$ & $\begin{array}{c}-0.18^{* * *} \\
(0.02)\end{array}$ & $\begin{array}{c}-0.19^{* * *} \\
(0.01)\end{array}$ \\
\hline Party $\times$ Importance & & $\begin{array}{c}-0.08^{* * *} \\
(0.03)\end{array}$ & $\begin{array}{c}-0.09^{* * *} \\
(0.03)\end{array}$ & $\begin{array}{c}-0.07^{*} \\
(0.04)\end{array}$ & $\begin{array}{c}-0.09^{* * *} \\
(0.03)\end{array}$ \\
\hline Scenario 2 & & & $\begin{array}{c}0.11^{* *} \\
(0.05)\end{array}$ & $\begin{array}{c}0.11^{* *} \\
(0.05)\end{array}$ & \\
\hline Scenario 3 & & & $\begin{array}{c}-0.01 \\
(0.04)\end{array}$ & $\begin{array}{c}-0.01 \\
(0.04)\end{array}$ & \\
\hline Party $\times$ Scenario 2 & & & & $\begin{array}{c}0.09 \\
(0.10)\end{array}$ & \\
\hline Party $\times$ Scenario 3 & & & & $\begin{array}{c}0.15 \\
(0.10)\end{array}$ & \\
\hline Infl Vote & & & & & $\begin{array}{l}0.12^{* * *} \\
(0.03)\end{array}$ \\
\hline Vote Mass Party & & & & & $\begin{array}{c}0.04 \\
(0.04)\end{array}$ \\
\hline AIC & 3172.46 & 2989.97 & 2992.19 & 2999.70 & 2818.77 \\
\hline $\mathrm{BIC}$ & 3198.81 & 3026.84 & 3039.57 & 3057.61 & 2865.68 \\
\hline Log Likelihood & -1581.23 & -1487.98 & -1487.09 & -1488.85 & -1400.39 \\
\hline Num. obs. & 1437 & 1437 & 1437 & 1437 & 1362 \\
\hline
\end{tabular}

Table 3: Models 1-5 with raw coefficients and standard errors in parentheses. GLS random effects models on acceptance of the decision, based on 479 participants with three decisions per participant. Model 5 has less observations because of missing data of actual voting behavior.

per se, or direct-democratic procedures do not seem to be superior per se, which corroborates hypothesis 1 .

As set out in hypothesis 2, we expect decisions by political parties to be less accepted than decisions through a direct-democratic procedure with increasing perceived importance of the issue. This effect is confirmed in model 2, where we add Importance as a main effect and as an interaction term with the Party variable. The more important a decision is for the respondent, the less it is accepted, controlling for personal opinion on the decision outcome. More interestingly, however, there is a strongly significant negative effect of the interaction term. An increase in importance leads to a decrease in acceptance. This effect is even stronger if the decision is made by a party instead of direct democracy. This finding confirms that citizens question decisions made by parties in situations where they are intrinsically 
motivated to get informed, whereas the decision-making procedure does not matter in less sensitive contexts. Apparently, political parties work well in everyday policymaking contexts where citizens do not have enough resources to acquire knowledge about current issues. In these situations, parties provide easy-to-grasp information packages, or "brands" or "labels" (Ashworth and Bueno de Mesquita 2008), which reduce information costs and increase efficiency for voters (Jones and Hudson 1998; Müller 2000; Nisbett and Ross 1992). This argument does not hold when voters find a decision so important that they inform themselves on the subject-no matter the cost of information. As soon as voters are intrinsically motivated to become wellinformed about a specific political problem, parties lose their function of serving as cognitive cues that would otherwise help the electorate choose policy positions on novel issues (Arceneaux 2008; Druckman 2001b; Zaller 1992). Voters rather feel intrinsically motivated to become informed and decide for themselves. Parties as intermediaries are one step removed from the electorate, their decisions are perceived as being beyond the control of the individual voter and decoupled from the electorate at large. For this reason, voters then tend to perceive parties as less legitimate decision-makers. The parties-as-brands or parties-as-labels argument thus has to be qualified.

Models 3 and 4 demonstrate that this effect is not driven by specific issues. Three different decision scenarios were presented to all respondents: nuclear energy (scenario 1), school graduation (scenario 2), and religious education (scenario 3). Even if the issue scenarios are introduced as main effects (model 3) or as additional interaction effects with the decision mode (model 4), the Party decision procedure leads to lower acceptance with increasing importance. These findings confirm hypothesis 3.

In model 5, we add two additional control variables in order to check for the robustness of our findings. The Infl Vote model term captures the extent of perceived political self-efficacy during the upcoming state-level election. Voters who tend to think that the electorate can actually change politics and policies by means 
of voting for representatives are more likely to accept decisions in general. However, this perceived self-efficacy does not diminish the interaction effect between importance of the issue and decision mode. Even if voters tend to think that their voting for parties can make a difference, they are less likely to accept party decisions if they are important to them.

The Vote Mass Party variable indicates the intention to vote for one of the two mass parties, SPD or CDU. The Party variable indicates decisions which are made either by SPD or CDU or the majority of parties in the parliament. One may argue that voters of these mass parties may be more supportive of decisions which are made by precisely these parties and less skeptical than other voters even when it comes to important decisions made by these parties. This is clearly not the case; again, controlling for this variable does not alter the coefficient of the interaction effect. Our finding is not conditional on party preferences.

\section{Taking into account decisions made by expert committees}

Model 6 in table 4 is a replication of model 2 based on the full dataset including decisions made by an expert committee besides parties and direct-democracy

- Apparently, parties no longer have lower acceptance rates if tested against the full reference group of direct-democracy and expert committee decisions. However, model 7 demonstrates that direct democracy is now significantly more accepted than the reference group of parties and expert committees when important issues are at stake. This supports our prediction (and in particular hypothesis 4) because in both decision-making arrangements, parties and expert committees, decisions are one step removed from the electorate, and the control perception is diminished.

Figure 1 visualizes these differences between the direct-democratic procedure and the decision procedures based on intermediaries. While intermediaries perform (insignificantly) better in terms of procedural acceptance for unimportant decisions (at importance level 1), direct-democracy performs slightly better on average (level 4) 


\begin{tabular}{|c|c|c|c|c|c|c|c|}
\hline & Model 6 & Model 7 & Model 8 & Model 9 & Model 10 & Model 11 & Model 12 \\
\hline (Intercept) & $\begin{array}{c}-2.33^{* * *} \\
(0.04)\end{array}$ & $\begin{array}{c}-2.33^{* * *} \\
(0.04)\end{array}$ & $\begin{array}{c}-2.34^{* * *} \\
(0.04)\end{array}$ & $\begin{array}{c}-2.33^{* * *} \\
(0.04)\end{array}$ & $\begin{array}{c}-2.33^{* * *} \\
(0.04)\end{array}$ & $\begin{array}{c}-2.44^{* * *} \\
(0.05)\end{array}$ & $\begin{array}{c}-2.46^{* * *} \\
(0.06)\end{array}$ \\
\hline Agreement & $\begin{array}{l}0.76^{* * *} \\
(0.01)\end{array}$ & $\begin{array}{l}0.76^{* * *} \\
(0.01)\end{array}$ & $\begin{array}{l}0.76^{* * *} \\
(0.01)\end{array}$ & $\begin{array}{l}0.76^{\text {*** }} \\
(0.01)\end{array}$ & $\begin{array}{l}0.76^{* * *} \\
(0.01)\end{array}$ & $\begin{array}{l}0.77^{* * *} \\
(0.01)\end{array}$ & $\begin{array}{l}0.79^{* * *} \\
(0.02)\end{array}$ \\
\hline Importance & $\begin{array}{c}-0.20^{* * *} \\
(0.01)\end{array}$ & $\begin{array}{c}-0.20^{* * *} \\
(0.01)\end{array}$ & $\begin{array}{c}-0.20^{* * *} \\
(0.01)\end{array}$ & $\begin{array}{c}-0.19^{* * *} \\
(0.01)\end{array}$ & $\begin{array}{c}-0.19^{* * *} \\
(0.01)\end{array}$ & $\begin{array}{c}-0.19^{* * *} \\
(0.01)\end{array}$ & $\begin{array}{c}-0.21^{* * *} \\
(0.02)\end{array}$ \\
\hline Party & $\begin{array}{c}-0.01 \\
(0.04)\end{array}$ & & & & & & \\
\hline Party $\times$ Importance & $\begin{array}{r}-0.03 \\
(0.02)\end{array}$ & & & & & & \\
\hline Direct Democracy & & $\begin{array}{c}0.04 \\
(0.05)\end{array}$ & $\begin{array}{c}0.04 \\
(0.06)\end{array}$ & $\begin{array}{c}0.04 \\
(0.06)\end{array}$ & $\begin{array}{c}0.04 \\
(0.06)\end{array}$ & $\begin{array}{c}0.05 \\
(0.06)\end{array}$ & $\begin{array}{c}0.06 \\
(0.06)\end{array}$ \\
\hline Direct Democracy $\times$ Importance & & $\begin{array}{l}0.09^{* * * *} \\
(0.03)\end{array}$ & $\begin{array}{l}0.10^{* * *} \\
(0.04)\end{array}$ & $\begin{array}{l}0.10^{* * *} \\
(0.04)\end{array}$ & $\begin{array}{c}0.09^{* *} \\
(0.04)\end{array}$ & $\begin{array}{l}0.11^{* * *} \\
(0.04)\end{array}$ & $\begin{array}{c}0.12^{* *} \\
(0.05)\end{array}$ \\
\hline SPD & & & $\begin{array}{c}-0.01 \\
(0.06)\end{array}$ & $\begin{array}{c}-0.01 \\
(0.06)\end{array}$ & $\begin{array}{c}-0.01 \\
(0.06)\end{array}$ & $\begin{array}{c}-0.03 \\
(0.06)\end{array}$ & $\begin{array}{c}0.01 \\
(0.06)\end{array}$ \\
\hline CDU & & & $\begin{array}{r}-0.04 \\
(0.06)\end{array}$ & $\begin{array}{r}-0.04 \\
(0.06)\end{array}$ & $\begin{array}{r}-0.04 \\
(0.06)\end{array}$ & $\begin{array}{c}-0.04 \\
(0.06)\end{array}$ & $\begin{array}{c}-0.04 \\
(0.06)\end{array}$ \\
\hline Parl & & & $\begin{array}{c}0.06 \\
(0.06)\end{array}$ & $\begin{array}{c}0.06 \\
(0.06)\end{array}$ & $\begin{array}{c}0.06 \\
(0.06)\end{array}$ & $\begin{array}{c}0.06 \\
(0.06)\end{array}$ & $\begin{array}{c}0.11^{*} \\
(0.06)\end{array}$ \\
\hline SPD $\times$ Importance & & & $\begin{array}{l}0.07^{*} \\
(0.04)\end{array}$ & $\begin{array}{r}0.07^{*} \\
(0.04)\end{array}$ & $\begin{array}{l}0.07^{*} \\
(0.04)\end{array}$ & $\begin{array}{l}0.10^{* *} \\
(0.04)\end{array}$ & $\begin{array}{l}0.11^{* * *} \\
(0.04)\end{array}$ \\
\hline $\mathrm{CDU} \times$ Importance & & & $\begin{array}{c}0.01 \\
(0.04)\end{array}$ & $\begin{array}{c}0.01 \\
(0.04)\end{array}$ & $\begin{array}{c}0.01 \\
(0.04)\end{array}$ & $\begin{array}{c}0.02 \\
(0.04)\end{array}$ & $\begin{array}{c}-0.01 \\
(0.04)\end{array}$ \\
\hline Parl $\times$ Importance & & & $\begin{array}{r}-0.01 \\
(0.04)\end{array}$ & $\begin{array}{c}-0.01 \\
(0.04)\end{array}$ & $\begin{array}{c}-0.01 \\
(0.04)\end{array}$ & $\begin{array}{c}0.00 \\
(0.04)\end{array}$ & $\begin{array}{c}0.01 \\
(0.04)\end{array}$ \\
\hline Scenario 2 & & & & $\begin{array}{l}0.12^{* * *} \\
(0.04)\end{array}$ & $\begin{array}{l}0.12^{* * *} \\
(0.04)\end{array}$ & $\begin{array}{l}0.11^{* * *} \\
(0.04)\end{array}$ & $\begin{array}{l}0.16^{* * *} \\
(0.05)\end{array}$ \\
\hline Scenario 3 & & & & $\begin{array}{r}-0.02 \\
(0.04)\end{array}$ & $\begin{array}{r}-0.02 \\
(0.04)\end{array}$ & $\begin{array}{c}-0.03 \\
(0.04)\end{array}$ & $\begin{array}{c}0.07 \\
(0.04)\end{array}$ \\
\hline Direct Democracy $\times$ Scenario 2 & & & & & $\begin{array}{c}-0.09 \\
(0.10)\end{array}$ & $\begin{array}{c}-0.08 \\
(0.11)\end{array}$ & $\begin{array}{c}-0.06 \\
(0.12)\end{array}$ \\
\hline Direct Democracy $\times$ Scenario 3 & & & & & $\begin{array}{c}-0.13 \\
(0.10)\end{array}$ & $\begin{array}{r}-0.09 \\
(0.10)\end{array}$ & $\begin{array}{r}-0.17 \\
(0.11)\end{array}$ \\
\hline Vote SPD & & & & & & $\begin{array}{c}0.02 \\
(0.04)\end{array}$ & $\begin{array}{c}0.00 \\
(0.05)\end{array}$ \\
\hline Vote CDU & & & & & & $\begin{array}{c}0.09^{*} \\
(0.05)\end{array}$ & $\begin{array}{c}0.11^{*} \\
(0.05)\end{array}$ \\
\hline Infl Vote & & & & & & $\begin{array}{l}0.09^{* * *} \\
(0.03)\end{array}$ & $\begin{array}{l}0.07^{* *} \\
(0.03)\end{array}$ \\
\hline $\mathrm{AIC}$ & 3846.43 & 3838.59 & 3869.98 & 3868.12 & 3876.20 & 3674.57 & 2785.82 \\
\hline $\mathrm{BIC}$ & 3885.03 & 3877.19 & 3941.63 & 3950.77 & 3969.85 & 3783.66 & 2889.78 \\
\hline Log Likelihood & -1916.22 & -1912.30 & -1921.99 & -1919.06 & -1921.10 & -1817.28 & -1372.91 \\
\hline Num. obs. & 1839 & 1839 & 1839 & 1839 & 1839 & 1746 & 1355 \\
\hline
\end{tabular}

Table 4: Models 6-12 based on the full dataset with raw coefficients and standard errors in parentheses. GLS random effects models on acceptance of the decision, based on 479 participants with three decisions per participant. Models 11 and 12 have less observations because of missing data of actual voting behavior. 


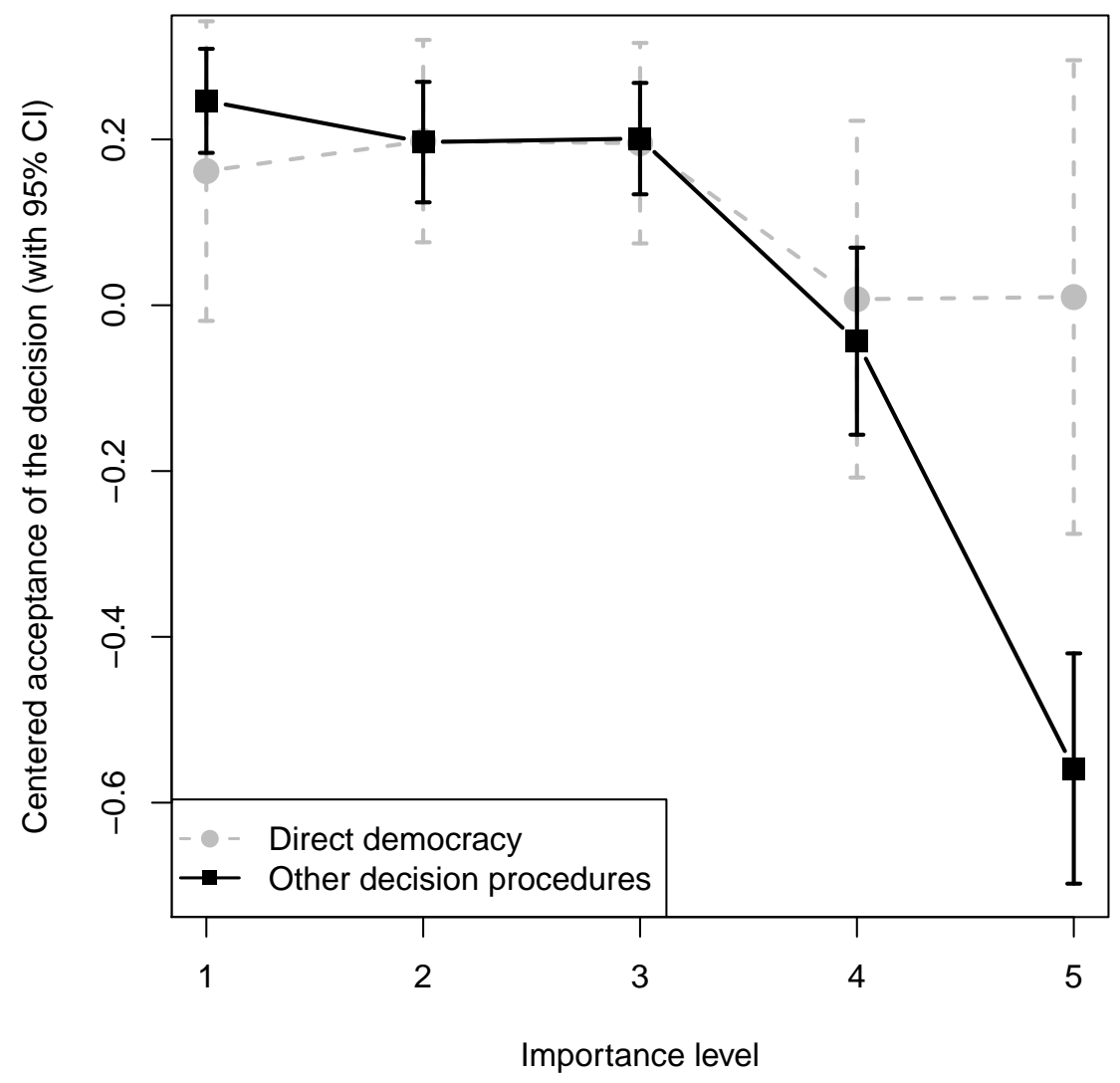

Figure 1: Centered acceptance rates by decision mode at different importance levels.

and highly significantly better (level 5) when the issue at stake matters to the voter personally (Mann-Whitney U-test: $p=0.00551$ ).

The remaining models provide additional checks for validity and omitted variable bias. Model 8, for example, disentangles the aggregate effect of political parties. Separate effects are included for SPD, CDU, the majority of parties in the parliament, and interaction terms with perceived importance of the issue to be decided for these variables. On the one hand, this lends more credible support to hypothesis 4 because the interaction effect between direct-democracy and importance is now tested against the reference group of expert committee decisions instead of a blend of expert committees and parties. On the other hand, we find that decisions made by the social-democratic party, SPD, are significantly more accepted with increasing issue 
importance than expert decisions while other party-related variables do not significantly deviate. The party effect may differ between party ideologies, although this effect may be related to the specific election under scrutiny. In any case, the plain information that parties in general - that is, the majority of parties in parliamentmake a decision does not seem to be different from expert decisions. This suggests that parties at large and expert committees are perceived to be similarly removed from public control, while specifically named parties may evoke stronger control perceptions because the decision is attributable to a more narrowly defined set of decision-makers. This, in turn, suggests that anonymity of the decision-maker may contribute to a diminished control perception, independently of the decision mode. Future research may shed more light on this question.

Models 9 and 10 replicate models 3 and 4 for the full dataset. They show that the interaction effect is not affected by the introduction of issue scenarios and only affected to a small extent by controlling for an interaction between party decisionmaking and specific scenarios, like in the models presented before.

Model 11 includes the same control variables as model 5, but again for the full dataset including expert decisions. Like in model 5, the positive effect of perceived self-efficacy of voters does not change the result. Instead of Vote Mass Party, we introduce two separate control variables this time - Vote SPD and Vote CDU - as there are also separate model terms for SPD and CDU in the model specification. Neither of the control variables changes the main results presented above, but the positive effect for SPD $\times$ Importance now stands out more clearly.

As an additional validity check, we exclude all observations where the personal opinion of the respondent is strongly positive; that is, we exclude all observations in model 12 where Agreement $=4$. We would expect that those who strongly agree with the decision anyway should not have any reason to be dissatisfied with the procedure. Accordingly, the main effect should still hold for the remaining groups and not be driven by this potential artifact. And indeed, the exclusion of these data does 
not alter the effect size or $p$ value of the interaction term. This suggests that the effect results from those who disagree and are overruled and those who only mildly agree. Finally, figure 2 visualizes the interaction effect as featured in model 11, the full model with all control variables. The acceptance of decisions generally declines with increasing importance of the issue, but it does so at a considerably faster rate in systems with intermediary decision-makers. As predicted by our theory, the latter seem to be more accepted in cases where the issue is less important, as indicated on the left in both subplots (although the difference is not significant), while direct democratic decisions are significantly more accepted for important decisions, as shown on the right in both diagrams. For decisions of medium importance, the procedure does not matter, especially where both prediction lines would cross each other if they were overlapped.

\section{Conclusion}

This paper addresses the question whether direct-democratic institutions or intermediaries like political parties lead to decisions with a higher acceptance among voters. Our findings suggest that there is no inherent taste for any of the institutions studied, irrespective of context. However, we find noticeable differences when we analyze the different acceptance that different decision processes generate depending on the relevance of the issue at stake. A direct-democratic procedure produced more accepted outcomes for highly relevant issues which matter to voters, while institutions

with intermediaries - like political parties or expert committees - seem to be slightly better equipped for low-importance, everyday decision-making situations.

Our analysis qualifies the literature on parties as brand names or labels. Ideological packages, which are offered as information short-cuts by political parties to reduce transaction costs, are only functional for ordinary decisions. 


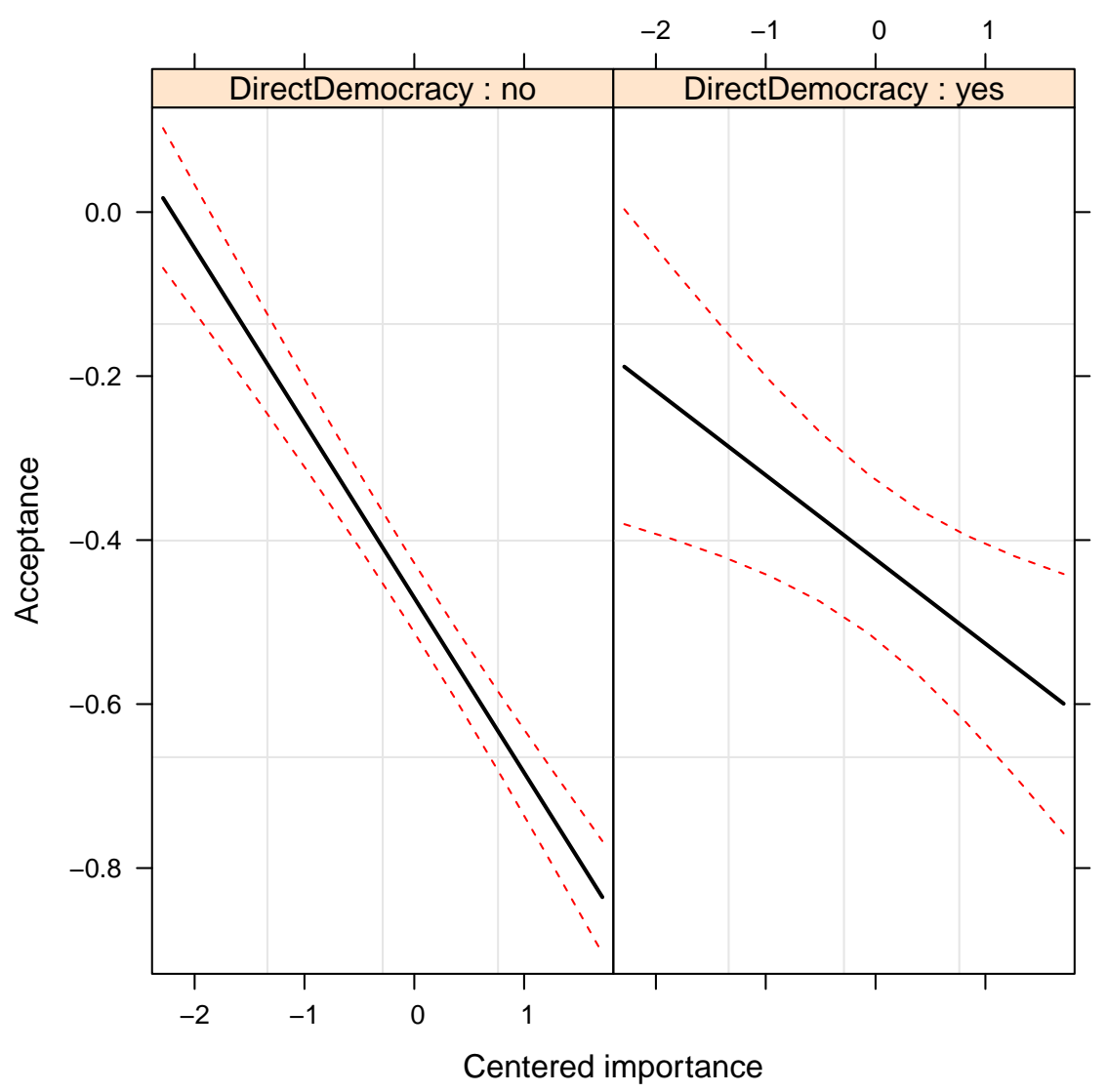

Figure 2: Effect display (Fox 2003) of the interaction effect in model 11 with $95 \%$ confidence intervals, fixing all other model terms.

In the perspective of input legitimacy or procedural utility, direct-democratic procedures are significantly more efficient when issues are perceived to be important. Why should this perspective matter at all, or at least more than output legitimacy and objective decision quality? The acceptance and thus legitimacy of core political institutions is a cornerstone of liberal democratic thinking (Cohen 1986; Riker 1982). A major divergence between acceptance of institutions and institutional reality might be more detrimental to the persistence of a polity than a major divergence between the actual and the desired efficacy of the same institutions. Future research may shed more light on the relation between both.

This severity of the issue might be one of the reasons for the adoption of directdemocratic expansion by several political parties in Western democracies (see Scar- 
row (1999)). With such movements, parties can increase acceptance and escape political disenchantment. Research on party systems will show how political parties will cope with the challenges outlined in this article (Katz and Mair 1995; Scarrow 1999), and whether they continue to be the dominant forms of political decisionmaking as in the last two centuries.

Our findings also have implications regarding the alleged "new protest culture" that is emerging in many countries (Hartleb 2011). Our theory and results provide a context for this development. Protests may be emerging because decision-makers fail to shift from party politics and "expertocracies" to mixed systems of representation and direct-democratic decision-making (Fischer 1999).

Finally, future research should delimit the boundaries of our findings. Our study was conducted in a Western European consensual democracy at the state level. Future research should explore the role of institutions like plurality versus proportional election systems or pluralist versus corporatist interest intermediation. While the amount of party divergence is similar under proportional representation and plurality rule (Ansolabehere, Leblanc and Snyder 2012), both may constrain procedural acceptance in complex ways. Furthermore, the institutions may themselves be a result of underlying cultural traits and preferences for majoritarianism or consensualism (this is, of course, also relevant for judicial reviews of controversial issue, e.g., decisions by the Supreme Court as investigated by Fontana and Braman 2012).

\section{References}

Aldrich, John H. 1995. Why Parties? The Origins and Transformation of Political Parties in America. Chicago and London: University of Chicago Press.

Ansolabehere, Stephen, William Leblanc and James M. Snyder, Jr. 2012. "When

Parties are Not Teams: Party Positions in Single-Member District and Proportional Representation Systems." Economic Theory 49:521-547. 
Arceneaux, Kevin. 2008. "Can Partisan Cues Diminish Democratic Accountability?" Political Behavior 30(2):139-160.

Ashworth, Scott and Ethan Bueno de Mesquita. 2008. "Informative Party Labels with Institutional and Electoral Variation." Journal of Theoretical Politics 20(3):251-273.

Auer, Andres. 2005. "European Citizens' Initiative." European Constitutional Law Review (EuConst) 1(01):79-86.

Barber, Benjamin R. 1984. Strong Democracy. Berkeley: University of California Press.

Becker, Gary S. 1958. "Competition and Democracy." Journal of Law and Economics 1:105-109.

Becker, Gary S. 1978. The Economic Approach to Human Behavior. Chicago: University of Chicago Press.

Benz, Matthias and Alois Stutzer. 2004. "Are Voters Better Informed When They Have a Larger Say in Politics?" Public Choice 119:31-59.

Bernard, Manin. 1997. The Principles of Representative Government. Cambridge: Cambridge University Press.

Bernhardt, Dan, John Duggan and Francesco Squintani. 2009. "The Case for Responsible Parties." American Political Science Review 103(04):570-587.

Bowler, S., T. Donovan and T. Happ. 1992. "Ballot Propositions and Information Costs: Direct Democracy and the Fatigued Voter." Western Political Quarterly $45(2): 559-568$.

Butler, Daniel M. and Eleanor Neff Powell. 2012. "Understanding the Party Brand." Yale University Mimeo. 
Clarke, Harold D. and Marianne C. Stewart. 1998. "The Decline of Parties in the Minds of Citizens." Annual Review of Political Science 1(1):357-378.

Cohen, Joshua. 1986. "An Epistemic Conception of Democracy." Ethics 97(1):26-38.

Cox, Gary W. and Matthew D. McCubbins. 1993. Legislative Leviathan: Party Government in the House. Berkeley: University of California Press.

Dalton, Russell J., Wilhelm Burklin and Andrew Drummond. 2001. "Public Opinion and Direct Democracy." Journal of Democracy 12(4):141-153.

Donovan, Todd and Jeffrey A. Karp. 2006. "Popular Support for Direct Democracy." Party Politics 12(5):671-688.

Downs, Anthony. 1957. "An Economic Theory of Political Action in a Democracy." The Journal of Political Economy 65(2):135-150.

Druckman, James N. 2001a. "The Implications of Framing Effects for Citizen Competence." Political Behavior 23(3):225-256.

Druckman, James N. 2001b. "Using Credible Advice to Overcome Framing Effects." Journal of Law, Economics, and Organization 17:62-82.

Easton, David. 1965. A Systems Analysis of Political Life. New York/London/Sydney: Wiley.

Esaiasson, Peter, Mikael Gilljam and Mikael Persson. 2012. "Which Decision-Making Arrangements Generate the Strongest Legitimacy Beliefs? Evidence from a Randomised Field Experiment." European Journal of Political Research 51(6):785-808.

Fischer, Frank. 1999. "Technological Deliberation in a Democratic Society: The Case for Participatory Inquiry." Science and Public Policy 26(5):294-302.

Fontana, David and Donald Braman. 2012. "Judicial Backlash or Just Backlash? Evidence from a National Experiment." Columbia Law Review 112(4):731-799. 
Fox, John. 2003. "Effect Displays in R for Generalised Linear Models." Journal of Statistical Software 8(15):1-27.

Freitag, Markus and Isabelle Stadelmann-Steffen. 2010. "Stumbling Block or Stepping Stone? The Influence of Direct Democracy on Individual Participation in Parliamentary Elections." Electoral Studies 29(3):472-483.

Frey, Bruno S. and Alois Stutzer. 2005. "Beyond Outcomes: Measuring Procedural Utility." Oxford Economic Papers 57(1):90-111.

Gash, Alison and Michael Murakami. 2009. "Courts, Legislatures, and Ballot Initiatives: How Policy Venue Affects Public Acceptance." Paper Presented at the APSA 2009 Toronto Meeting.

Gibson, James L. and Gregory A. Caldeira. 1995. "The Legitimacy of Transnational Legal Institutions: Compliance, Support, and the European Court of Justice." American Journal of Political Science 39(2):459-89.

Hajnal, Zoltan L., Elisabeth R. Gerber and Hugh Louch. 2002. "Minorities and Direct Legislation: Evidence from California Ballot Proposition Elections." Journal of Politics 64(1):154-177.

Hartleb, Florian. 2011. "A New Protest Culture in Western Europe?" European View 10:3-10.

Hasen, Richard L. 2000. "Parties Take the Initiative (And Vice Versa)." Columbia Law Review 100(3):731-752.

Heidenheimer, Arnold J. and Michael Johnston, eds. 2002. Political Corruption. New Brunswick: Transaction Publishers.

Jones, Philip and John Hudson. 1998. "The Role of Political Parties: An Analysis Based on Transaction Costs." Public Choice 94(1-2):175-189. 
Karp, Jeffrey A., Susan A. Banducci and Shaun Bowler. 2003. "To Know it is to Love it? Satisfaction with Democracy in the European Union." Comparative Political Studies 36(3):271-292.

Katz, Richard S. 1990. "Party as Linkage: A Vestigial Function?" European Journal of Political Research 18(1):143-161.

Katz, Richard S. and Peter Mair. 1995. "Changing Models of Party Organization and Party Democracy: The Emergence of the Cartel Party." Party Politics 1(1):5-28.

Klein, Markus. 2005. "Die Entwicklung der Beteiligungsbereitschaft bei Bundestagswahlen." Kölner Zeitschrift für Soziologie und Sozialpsychologie 57(3):494-522.

Lacey, Robert J. 2005. "The Electoral Allure of Direct Democracy: The Effect of Initiative Salience on Voting." State Politics and Policy Quarterly 5(2):168-81.

Leighley, Jan and Jonathan Nagler. 1992. "Individual and Systemic Differences on Turnout: Who Votes: 1983-1987." Journal of Politics 54:635-717.

Lupia, Arthur and John G. Matsusaka. 2004. "Direct Democracy: New Approaches to Old Questions." Annual Review of Political Science 7:463-482.

Martinelli, Cesar. 2006. "Would Rational Voters Acquire Costly Information?" Journal of Economic Theory 129(1):225-25.

McCormick, Robert E. and Robert D. Tollison. 1979. "Rent-Seeking Competition in Political Parties." Public Choice 34(1):5-14.

Mendelsohn, Matthew and Fred Cutler. 2000. "The Effect of Referendums on Democratic Citizens: Information, Politicization, Efficacy and Tolerance." British Journal of Political Science 30(4):669-698.

Müller, Wolfgang C. 2000. "Political Parties in Parliamentary Democracies: Making Delegation and Accountability Work." European Journal of Political Research 37(3):309-333. 
Nisbett, Richard E. and Lee Ross. 1992. Human Inference: Strategies and Shortcomings of Social Judgment. Englewood Cliffs: Prentice-Hall.

Nordhaus, William D. 1975. "The Political Business Cycle." The Review of Economic Studies 42(2):169-190.

Olken, Benjamin A. 2010. "Direct Democracy and Local Public Goods: Evidence from a Field Experiment in Indonesia." American Political Science Review 104(02):243-267.

Palfrey, Thomas R. and Howard Rosenthal. 1985. "Voter Participation and Strategic Uncertainty." The American Political Science Review 79(1):62-78.

Pateman, Carole. 1970. Participation and Democratic Theory. New York: Cambridge University Press.

Petty, Richard E. and John T. Cacioppo. 1986. "The Elaboration Likelihood Model of Persuasion." Advances in Experimental Social Psychology 19:124-205.

Riker, William H. 1982. Liberalism against Populism: A Confrontation between the Theory of Democracy and the Theory of Social Choice. San Francisco: W. H. Freeman.

Rosenstone, Steven J. and John Mark Hansen. 2003. Mobilization, Participation, and Democracy in America. New York: Longman.

Scarrow, Susan E. 1999. "Parties and the Expansion of Direct Democracy." Party Politics 5(3):341-362.

Scarrow, Susan E. 2001. "Direct Democracy and Institutional Change." Comparative Political Studies 34(6):651-665.

Scharpf, Fritz W. 1999. Governing in Europe. Democratic and Efficient? Oxford: Oxford University Press. 
Schlesinger, Joseph A. 1975. "The Primary Goals of Political Parties: A Clarification of Positive Theory." American Political Science Review 69(3):840-849.

Schlesinger, Joseph A. 1984. "On the Theory of Party Organization." The Journal of Politics 46:369-400.

Schuck, Andreas R. T. and Claes H. de Vreese. 2011. "Public Support for Referendums: The Role of the Media." West European Politics 34(2):181-207.

Smith, Mark A. 2002. "Ballot Initiatives and the Democratic Citizen." The Journal of Politics 64(03):892-903.

Snyder, Jr., James M. and Michael M. Ting. 2002. "An Informational Rationale for Political Parties." American Journal of Political Science 46(1):90-110.

Stutzer, Alois and Bruno S. Frey. 2000. "Stärkere Volksrechte - Zufriedenere Bürger: Eine mikroökonometrische Untersuchung für die Schweiz." Swiss Political Science Review 6(3):1-30.

Tolbert, Caroline J. and Daniel A. Smith. 2005. "The Educative Effects of Ballot Initiatives on Voter Turnout." American Politics Research 33(2):283-309.

Tyler, Tom R. 2006. Why People Obey the Law. Princeton: Princeton University Press.

Vatter, Adrian and Deniz Danaci. 2010. "Mehrheitstyrannei durch Volksentscheide? Zum Spannungsverhältnis zwischen direkter Demokratie und Minderheitenschutz." Politische Vierteljahresschrift 51(2):205-222.

Zaller, John. 1992. The Nature and Origins of Mass Opinion. New York: Cambridge University Press. 